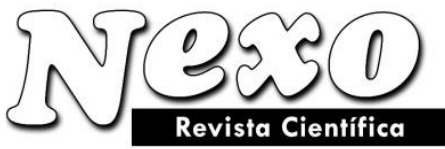

ISSN-E 1995-9516

Universidad Nacional de Ingeniería COPYRIGHT @ (UNI). TODOS LOS DERECHOS RESERVADOS

http://revistas.uni.edu.ni/index.php/Nexo

https://doi.org/10.5377/nexo.v33i02.10778

Vol. 33, No. 02, pp. 378-391/Diciembre 2020

(c) (i) $\odot$

\title{
Native house designing pattern recognition in Mazandaran province with climatic approach
}

\section{Reconocimiento de patrones de diseño de casas nativas en la provincia de Mazandaran con enfoque climático}

\author{
Azadeh Mahmoudi Kohneh Rood Posht ${ }^{1}$, Khosro Daneshjoo ${ }^{2, *}$, Seyed Majid Mofidi Shemirani ${ }^{3}$ \\ 1 Department of Architecture, Science and Reasearch Branch, Islamic Azad University, Tehran, \\ Iran. \\ 2 Assistant Professor, Department of Art and Architecture, Tarbiat Modares University, Tehran, \\ Iran. \\ 3 Assistant professor ,School of Art and Urban Studies, Iran University of Science and Technology, \\ Tehran, Iran. \\ *Corresponding author email: Kh-daneshjou@srbiau.ac.ir
}

(recibido/received: 02-June-2020; aceptado/accepted: 04-August-2020)

\begin{abstract}
In Forming residential house in Khazar's shore, climatic condition plays a basic role because in them had used of natural energy and environmental condition for heating, cooling and air conditioning. With studying, recognition and analyses of principles and patterns of native architecture can find out the compatibility of them with the climatic condition. With appearing modern architecture and destroying construction identity, patternology is one of the important issues that wants to find the practical methods for accessing to identity maker elements and patterns of past and using of them in now a day modern architecture. Traditional residential texture as the fundamental core of cities and so elements and architecture construction in them undoubtedly are worthy heritage for studying and analyzing and presenting proper patterns of native architecture. In this study first with an analyzing- descriptive approach have an overview and then the skeletal factors affecting texture and traditional residential constructions of Mazandaran province patternology are identified. Study method in this method is analyzing-descriptive and used of fieldwork for fundamental recognition and identifying for sample structures that are under studying. Finally, due to the obtained results, principles of native architecture and comparison of available criteria, native house designing patterns will present.
\end{abstract}

Keywords: native house of Mazandaran, climate, climatic patterns.

\section{RESUMEN}

Las condiciones climáticas juegan un papel clave en la formación de casas residenciales en la costa del Caspio porque utilizan energía natural y condiciones ambientales para la calefacción, refrigeración y aire acondicionado. Al estudiar, reconocer y analizar los principios y patrones de la arquitectura indígena, podemos descubrir su compatibilidad con las condiciones climáticas. Con el advenimiento de la 
arquitectura moderna y la destrucción de la identidad estructural, el modelado es uno de los temas importantes que quiere encontrar formas prácticas de lograr los elementos y patrones de identidad del pasado y utilizarlos en la arquitectura moderna. El tejido residencial tradicional como núcleo básico de las ciudades y por tanto los elementos y la construcción de la arquitectura en ellas es sin duda un patrimonio digno para el estudio y análisis y presentación de patrones adecuados de la arquitectura indígena. En este estudio, primero con un enfoque descriptivo-analítico, una visión general y luego se identifican los factores esqueléticos que afectan la textura y las construcciones residenciales tradicionales de la provincia de Mazandaran. Método de estudio En este método, el análisis descriptivo y el uso del trabajo de campo para identificar los conceptos básicos e identificar las estructuras muestrales en estudio. Finalmente, de acuerdo con los resultados obtenidos, se presentan los principios de la arquitectura indígena y la comparación de los criterios existentes, los patrones de diseño de las casas indígenas.

Palabras claves: Casa nativa de Mazandaran; Clima; Patrones climáticos.

\section{INTRODUCTIÓN}

Iran's native architecture elements are mostly affected by environmental factors and the miracle of native architecture in use of regional material and creating new construction techniques as the best method of responsibility to human physical and mental needs for constructing is not hidden for any one. Surveying native houses is a small step in recognition of technique and knowledge of builders when traditional materials and tools gave limited facilities. In these constructions in addition to outer properties, the building plan in functional order in different seasons determined based on climatic factors. In this way the uses of nonrenewable energies decrease to minimum and construction energy needs supply from renewable energies and this causes increasing comfort level. In the past half open spaces in general and porch in special were important spaces in houses. Identical properties of today houses in different climates and sub climates causes different problems of wasteful fuel using. Mild and humid climate had expanded in south coast of Khazar lake in the Mazandaran at the north of Iran. Pay attention to native architecture and climatic factors in this region can leads to better patterns that an addition to low using of fuel achieve better and higher level of comfort (Halabian, 2012).

\section{Materials and Methods}

The data in this study will be gathered through case study. Case studies allow for gathering in-depth and detailed information on the case of study. In-depth and careful examination, Focus on real events in real contexts in limited time and space and holistic view are the features of case study. This type of study is proper for theory making and theory testing. So in the context of this research it can be very effective. Observation and studying documents are The main methods of data gathering is in this study.

Discussion: Different components will be discussed in order to study the native and traditional architecture of Mazandaran.

The physical structure of traditional houses: The architectural elements of the Mazandaran's traditional houses can be described as space elements. The most important feature of the traditional house organization of this area is the simultaneous presence of three types of open space (courtyard), semi-open space (veranda) and closed space (rooms). Each of these spaces, depending on the livelihood or lifestyle of the families, had been useful and vivid spaces.

a- Open and semi-open space (courtyard and veranda): Courtyard and porch are two indivisible elements of traditional houses in this area Which were particularly dynamic because of their daily activities such as agriculture, animal husbandry and cooking. The courtyard and the porch were also used as a place to interact with nature and neighbors (social interactions) (Yazdanfar, Hosseini, Zaroudi, 2013). 


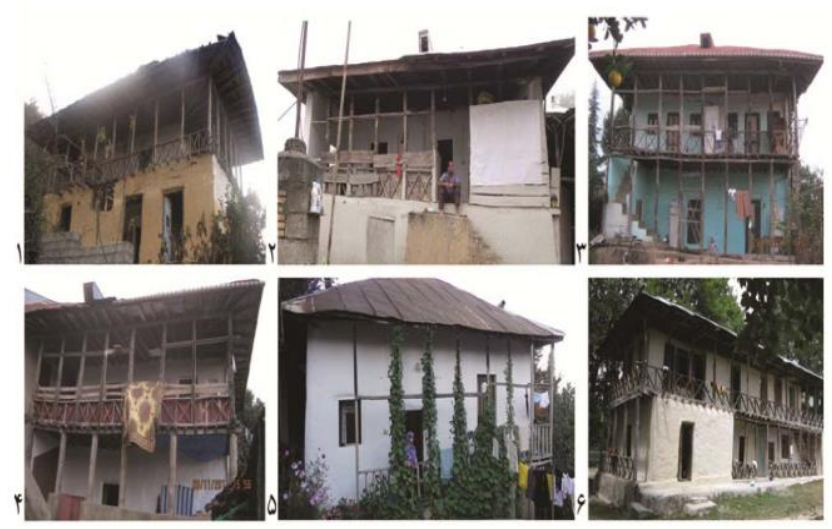

Figure 1: porch in Rural House in Mazandaran

b- Closed spaces: closed spaces or Indoors in Traditional houses consist of one or more rooms, kitchens and toilets. Closed spaces are multifunctional spaces where all the activities of a household such as eating, sleeping, gathering together, etc. can be performed there. Hence, in the traditional societies of this area, the room was called "home" and in construction was concerned with such things as the location, size, and function of the room. As most of the traditional families in the area were overcrowded due to occupational conditions (agriculture and animal husbandry) and the need for manpower, expecting personal room for each person was not available. As a result, the interior design of the rooms was designed to meet the needs of all family activities. exist multiple shutters for objects and decorations, large closets on the wall for clothes or bedding, many pillows and mattresses to sit in all rooms and some decorative details suggest this way of life(Figure 2). In the early species, cooking was also done outdoors, in which porch had a very close functional relationship with it.

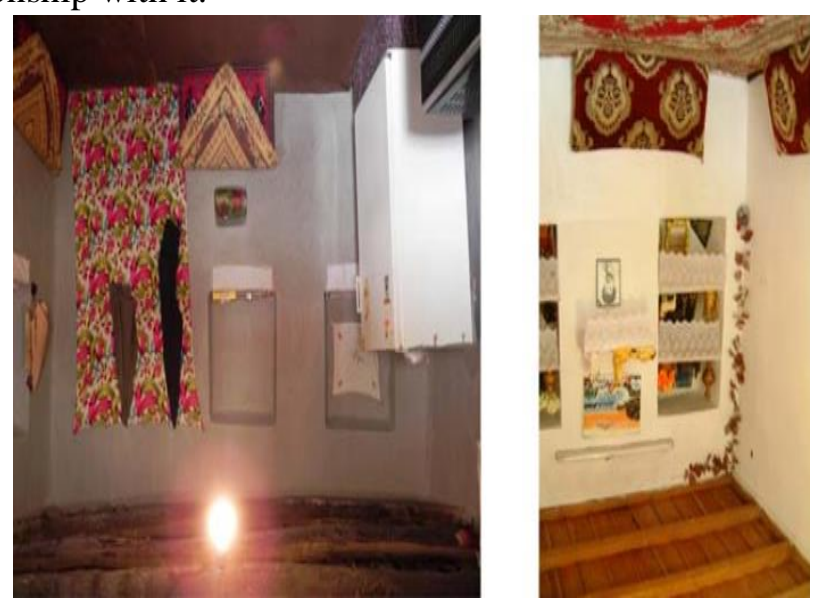

Figure 2 :Shutters in a multifunctional room.

in order to save privacy of women in home and making cooking easier, the bottom of the room In the later species was used as a kitchen. Toilets was another traditional indoor space built outside due to climatic conditions and lack of plumbing This helps to maintain the cleanliness of interior spaces, while preventing moisture from moving into the interior components and elements and Depreciation them.

\section{Spatial arrangement}


Indicative features that can be suggested in relation to the spatial organization of these houses are the planning pattern of these houses and their functional relationships. According to observations, the dominant patterns of traditional houses in this area can be restricted to the "I" shape or linear pattern, the "L" shape, and the "U" shape. The most important factor that these patterns were considered by traditional home builders is the privacy and separation of public and private (guest and family) before entering the home. In the aforementioned patterns, the guesthouse had a separate entrance and the porch was used as a pre-entrance part to that place(3\&4). Another point that was rooted in the beliefs of the people in this area was the orientation of the main building on the porch or entrance to the east or in Qiblah orientation, except where the shape and location of the land were restricted. According to locals, this type of orientation took place for various reasons. Regarding orientation to the south, the diagnosis of Qiblah at home (especially for the guest) is the reason for this type of orientation. But the main reason most of them agreed was the time between leaving home and starting daily activities in the name of God and in the direction of Qiblah. Orientation to the east also, for reasons cited by the people of the region, was related to coordinating the time between leaving home for daily commencement with sunrise. Some also refer to this kind of orientation as the city of Mashhad is located in the east of Mazandaran province and know this such as a respect to Imam Reza(Narimani, 2012).

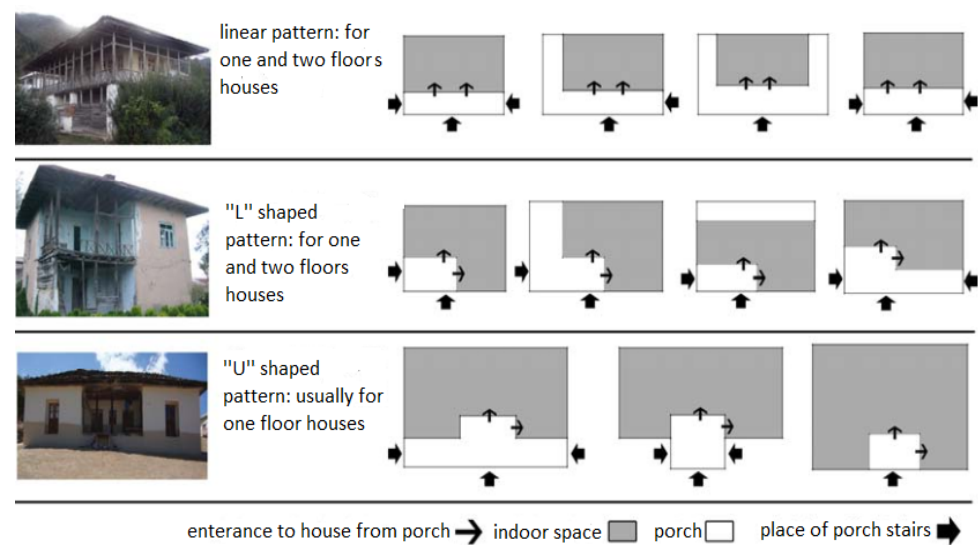

Figure 3: Examples of Forms of Traditional Houses in Mazandaran Region

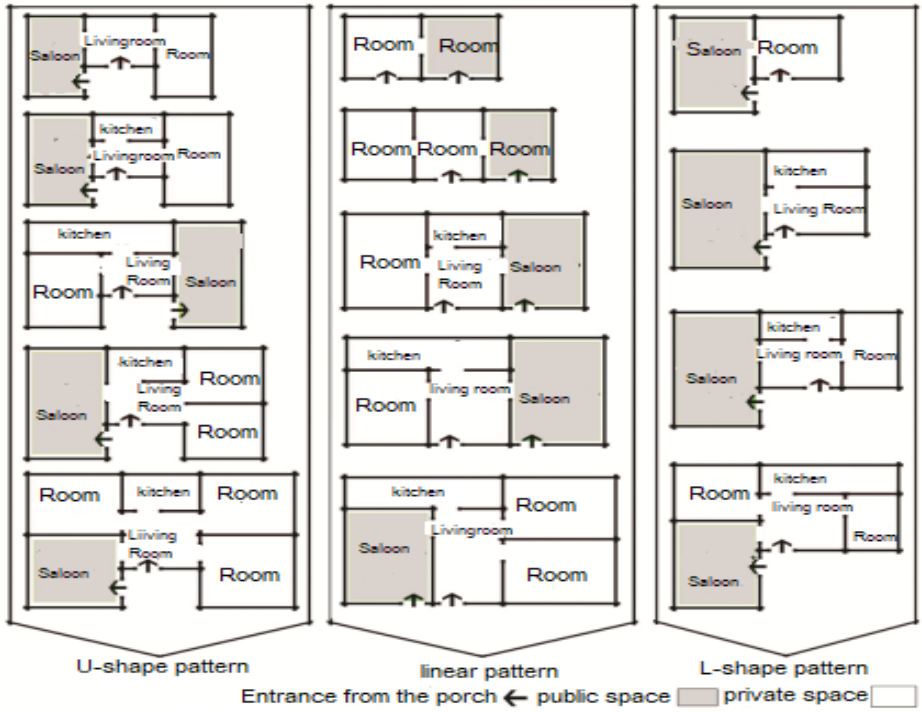

Figure 4: pattern of spaces

skeletal form: One of the prominent features of the traditional houses form in this region is the use of simple and regular shapes and geometries, human proportions and native and natural materials in their 
construction. These all imply that the indigenous architecture of this region, like that of other parts of Iran, is introverted. Means that, the exterior form is simple, without any extravagance, and the outer structure is a cover for the breathtaking interior space. In cases where exterior decorations were used, the decorations were mainly confined to natural elements such as flower pots on porch railings or window sills that gave the environment a special touch. Concerning the relationship between the physical form of the houses and the context on which they were built, the builders were more concerned with the coordination of materials, colors, and forms used with the context and climate of the area. So that the main materials used are stone, wood, plywood, lath, which have the warm colors which sit the best on the green background. The warm colors create a harmony in the spring and summer with the green surrounding and the autumn with the colorful textured background, and in some snowy winters the white creates a variety of pleasing contrast. These materials were easily available due to the numerous forests and rivers in the area. The sloping roof forms in addition to responding to climatic constraints (severe rainfall and the introduction of winter cold and summer heat) along the Alborz Mountains that can be seen from all parts of the region(Gedaali, Afshari \& Sadvandi, 2018).

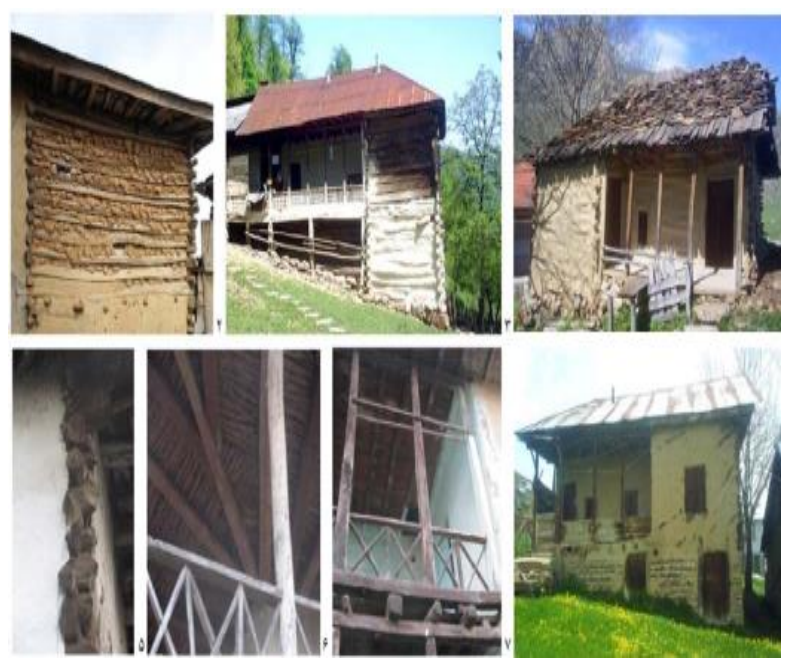

Figure 5: Harmony of traditional house materials and color with natural texture around the photo

In fact, by classifying the aspects and dimensions that residents put forward as influencing factors on the shape of their homes, in terms of value concepts, one can classify the impact of the category of culture on the shape of their homes. According to the theoretical framework presented in this study, this classification can be done in two parts: The first part deals with how to express the theoretical foundations derived from the values derived from people's worldview in traditional home architecture(table 1), The second part deals with the impact of the values mentioned on the traditional home architecture pattern through the orientation to the lifestyle and behavioral pattern of the people in the traditional communities of the region. In the first part, by observing the species and classifying their features, a comparative comparison of the stated reasons for each feature with the issues raised as theoretical foundations of Iranian-Islamic architecture was made. Then, the roots of these foundations were explored and referenced in value concepts derived from the worldview of the people of the region were researched and pointed as an example. For example, the orientation of the entrance area of traditional houses of the region to Qibla corresponds to the principle of symbolism or cryptography in Iranian-Islamic architecture which At a higher level by deciphering the causes put forward by residents This can be seen as an example of valuable concepts such as trust in God that is highly recommended in religious doctrines or Localization of materials in these houses refers to the principle of self-reliance and avoidance of futility in IranianIslamic architecture Which is the result of the principle of contentment, which has also been one of the important value concepts in their religious teachings, and many orders have been made in this regard(Yazdanfar, Hosseini, Zaroudi, 2013). 
Native architecture style: Native architecture is not detached from its surroundings, and it always takes into account design conditions, the environment, native materials and construction traditions in design. Approaches to native architecture and productive structure: Given the different approaches to native architecture and the definitions that each approach to indigenous architecture has, the four determinants of indigenous architecture can be considered the same factors that drive sustainable development. Nature, people (society), can construct and known as a pattern. Depending on the importance of each of these factors in different approaches to indigenous architecture, one can have distinct categories of definition for indigenous architecture that correspond to its relation to sustainable development. So in this tutorial, a five-category classification with the following patterns is presented (Akrami \& Damiar, 2017).

Table 1: Classification of cultural factors and their impact on the architecture of traditional houses based on theoretical foundations of architecture

\begin{tabular}{|c|c|c|c|}
\hline worldview & value & $\begin{array}{l}\text { Theoretical } \\
\text { Foundations } \\
\text { of architecture }\end{array}$ & Architecture pattern(house shape) \\
\hline \multirow{5}{*}{$\begin{array}{l}\text { Religious } \\
\text { Backgrou } \\
\text { nd(cultura } \\
1 \& \\
\text { religious) }\end{array}$} & $\begin{array}{l}\text { Hope, effort } \\
\text { and } \\
\text { perseverance }\end{array}$ & Symbolic Functions & $\begin{array}{l}\text { Orientation to east: The orientation of the facade where } \\
\text { the entrance is located is mostly to the east unless there } \\
\text { are restrictions on the shape of the earth (a kind of } \\
\text { metaphorical relationship between leaving home and } \\
\text { starting daily activities with sunrise) }\end{array}$ \\
\hline & $\begin{array}{l}\text { Trusting and } \\
\text { Obedience }\end{array}$ & Symbolic Functions & $\begin{array}{l}\text { Orientation to Qiblah: The orientation of the main facade } \\
\text { of the building (the facade where the entrance is located) } \\
\text { is mostly to the Qiblah unless there are restrictions on } \\
\text { the shape of the earth (to indicate the orientation of the } \\
\text { Qiblah, especially for guests and the need for a } \\
\text { metaphorical relationship between the time of departure } \\
\text { Home and starting daily activities with the sentence " } \\
\text { hope to God" }\end{array}$ \\
\hline & $\begin{array}{l}\text { Satisfaction } \\
\text { (Avoid } \\
\text { extravagance) }\end{array}$ & $\begin{array}{l}\text { Self-sufficiency } \\
\text { Functionalism }\end{array}$ & $\begin{array}{l}\text { futility: making maximum use of space and } \\
\text { Components } \\
\text { Indigenous materials in home construction (stone, wood, } \\
\text { lattice). } \\
\text { Energy Saving: Orientation of the house and the } \\
\text { openings to the cool day breeze (from the sea) and the } \\
\text { night sky (from the summit of the mountain). }\end{array}$ \\
\hline & Humility & $\begin{array}{l}\text { Avoid } \\
\text { Show off }\end{array}$ & $\begin{array}{l}\text { Introversion: superiority of the interior of the house over } \\
\text { its exterior } \\
\text { harmony between nature and texture around it (in terms } \\
\text { of materials and colors): wood and laminate-like } \\
\text { materials that have warm colors } \\
\text { And bright colors on the walls (mostly white) that } \\
\text { complement the warm colors of the materials }\end{array}$ \\
\hline & Discipline & $\begin{array}{l}\text { Form Properties, Space, } \\
\text { and Performance } \\
\text { Centrality Hierarchy }\end{array}$ & $\begin{array}{l}\text { The existence of open, semi-open and closed spatial } \\
\text { hierarchies - the existence of public and private spatial } \\
\text { hierarchies } \\
\text { The use of linear and central patterns in spatial form and } \\
\text { organization }\end{array}$ \\
\hline
\end{tabular}

People Partnership-based approach: Sometimes indigenous architecture is defined by the fact that it is built by the people themselves and that the professionals do not interfere. In this case, the term "architecture without an architect" could be derived from this view. For example, describing native architecture as: "Every nation that has founded its own architecture has exhibited its own distinctive lines and forms that are specific to their local language, habits and customs" (Fathi, 1993). Rapoport also says: 
"Folk architecture is the favorable environment of a people, who, without the intervention of architects, artists, or decorators, for a specific purpose, appears in buildings and houses" (Rapoport, et al, 2009). As such, "Native architecture speaks of a distinct local culture. The culture that is formed by the people in the same place grows and is affected by difficult events. But it fits into the culture of the same people with the native culture"(Memarian, 2008). The relation of this definition to the four architectural generating factors is summarized in Figure 6.

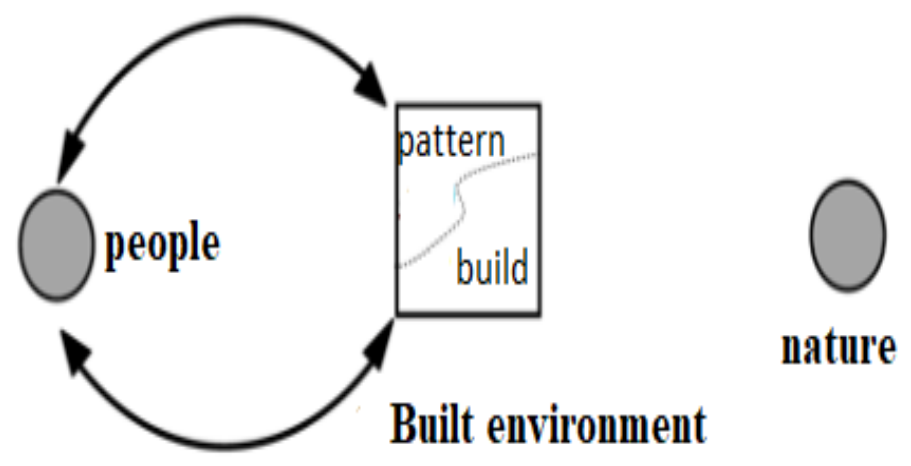

Figure 6: The Relationship between Architectural Productive Factors in a People-Based Approach(Akrami \& Damiar, 2017).

An example of this approach can be seen in the Mexican project in which Alexander suggested a new construction method that would be fully accessible to ordinary people, considering one of the major barriers to public participation in design, that is, the expertise of construction technology (Alexander, 2011).

The natural constructivism- based approach: Although folklore, and making folk language are inherent in most of the definitions of indigenous architecture, but in relation to nature, giving priority to material and natural possibilities, with the conceptual impact of nature, makes two distinct types of definitions with distinct application. In the first case, indigenous architecture is a primitive and past thing and a first step in human evolution; So among the definitions, the following statement leaves less chance for a contemporary approach (in any context, including sustainable architecture) to an indigenous architecture approach. Because it will be difficult to accept the return to technology that is known as primitive: " Native architecture includes settlements and other public buildings that depend on the context and resources available to them. These buildings are built by the individual (owner) or community using traditional technologies. All forms of indigenous architecture are created to meet specific needs in accordance with their values, cultures, methods and habits of life, production and economics"(Olivier, 2003). For example, in the new Gorna project, Fathi has utilized all of the indigenous construction capacity in harmony with nature to create a new physical environment (Fathi, 1993). 


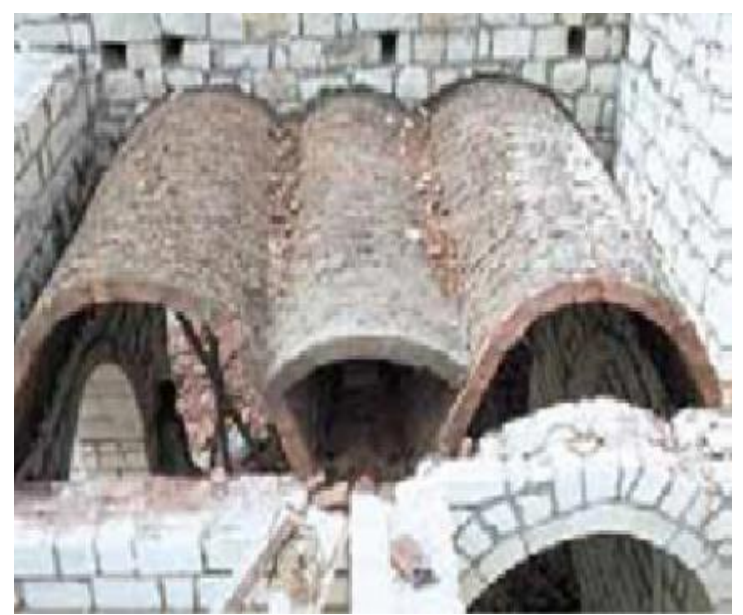

Figure 7: New Gornais Project - Build using native materials and native technology (Serageldin, 2007).

Natural model- based approach: In this approach, indigenous architecture, by being conceived of as having a conceptual connection with nature, finds a timeless quality that is ascribed to human timeless connection to nature. In indigenous communities, the compatibility between people and buildings (Architectural Framework) is deep. In these societies," every part of architecture is meaningful and is based on the experience and understanding of the indigenous people of life and existence. Hence it is formed correctly. Because the indigenous man feels it deeply and measures it with a tone and then creates it. So a whole is formed in a coherent whole. In fact, even the smallest coherent one contributes to the creation and preservation of the whole"(Alexander, 2011). On the other hand, indigenous architecture is a generalized design method born of folk architecture and can be considered as an advanced form of natural architecture of a given line that is expressed in relation to climate, culture and building materials. But indigenous architecture is inherently limited to features that the term "native" implies it the best. "The scale" in this architecture is the determining factor. Native architecture is harmonious with the people and with the environment (Alsope, 1992). An example of this approach can be seen in the Walter Segal project, which he has been developing since the decade of the 1960s for the construction of a low-cost, non-dense construction by the people themselves that, according to Nicholas Taylor, leads to a garden pattern. It becomes a real city in contemporary cities(Towers, 2003).

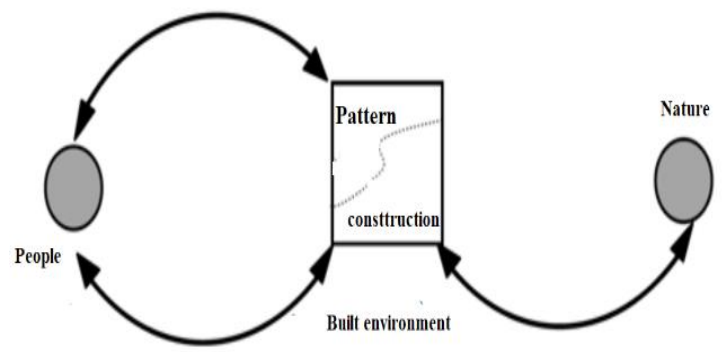

Figure 8: The Relationship between Architectural Generating Factors in the Approach Based on Natural Constructivism.

The approach based on natural absolutism: Among the approaches that have long been to indigenous architecture and its culmination in the nineteenth century, an absolutist view of nature stands out. The approach to regard architecture as the product of nature, and even in some attitudes, man is the product of nature. The continuity of this approach is also seen among contemporaries. In the contemporary Indian architect Balrakshna Duchi's ideas, the influence of the canvas is directly adapted to the architectural form. But more importantly, the canvas pattern, in his view, implies a kind of connection with nature. In other words, in the analysis of Balrishna Duchi's work, the way the architectural space is harmonized with 
nature has been revealed by the acquisition of deeper layers of nature. For this reason, the impact of the canvas has not only been shown to be in harmony with the general needs of the people, indigenous practices and indigenous forms, It also expresses other aspects of nature. In architectural analysis of him, can identify a deep understanding of all of India's cultural and social history and analyze the deep connection between the mind of the architect and nature (Nourmohammadi, 2009).

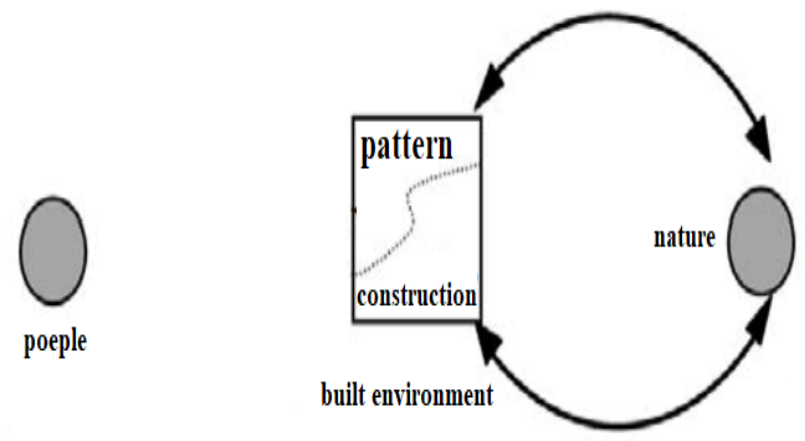

Figure 9: The Relationship between Architectural Productive Factors in the Approach Based on Natural Absolutism (Akrami \& Damiar, 2017).

Christofredi's Naturalist Architecture in the last two decades, which he describes in detail in The Soulful Places, is an example of all-naturalism in architecture. he has been Not only fully naturalistic in construction techniques and materials (with extensive use of soil and natural stone), he has also been completely naturalistic in the spatial patterns and concepts of outer space, relying on organic forms and natural health patterns.

Holographic-based approach: Native architecture may be the result of all the productive factors, that is, the whole of the natural-social life of man in his innate and endogenous state. Flameki, referring to the popularity of indigenous architecture, considers the connection with two types of environments to be the main features of indigenous architecture:" Link to the cultural environment or to the set of cultural values, to the set of cultural behaviors and to the set of implicit laws in one hand, and Link to the natural environment or to human-made datasets on the other hand. Data that are both intellectual and applied tools; both color, size, and proportion, as well as building materials and components"(Kamalipour, Memarian \& Mousavian, 2012). In fact, a purely spatial-cultural product so you can say: "Native architecture is another branch of tradition-based architecture that relies, above all, on the place and culture of the place on which it is situated. While benefiting from the common principles of space organization, this architecture retains its distinctive architectural accent in the composition and arrangement of space, the use of eco-friendly materials, the coverage of views and arches"(Haeri, 2005). 


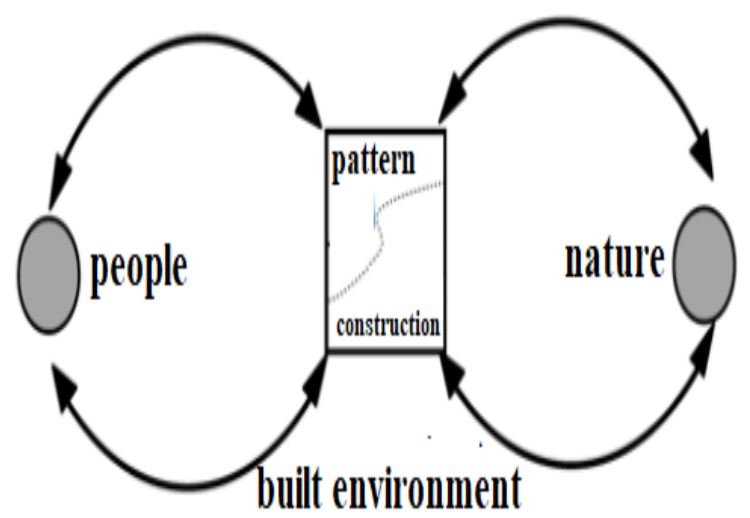

Figure10: The Relationship between Architectural Generating Factors in the Holistic Approach.

A typical example of this approach is the Grameen Bank project, an all-encompassing sustainable development project that started in Bangladesh in the 1980s and has an important role in influencing indigenous architecture.

Given these approaches, how to utilize native architecture to achieve sustainable architecture can be presented in five different ways. Table 2 summarizes these species and their relation to sustainable architecture along with a contemporary example of this type of exposure to both sustainable architecture and native architecture (Akrami \& Damiar, 2017).

Table 2: The relationship between sustainable architecture and approaches to indigenous architecture.

\begin{tabular}{|l|l|l|l|l|}
\hline & $\begin{array}{l}\text { Approaches } \\
\text { Native Architecture }\end{array}$ & $\begin{array}{l}\text { The relationship between sustainable architecture and approaches } \\
\text { to indigenous architecture }\end{array}$ & Case examples \\
\hline $\mathbf{1}$ & $\begin{array}{l}\text { People Partnership- } \\
\text { based approach }\end{array}$ & $\begin{array}{l}\text { Native Architecture is a usable example of sustainable architecture } \\
\text { through popular construction techniques and collaborative patterns }\end{array}$ & $\begin{array}{l}\text { The Mexican Project } \\
\text { (Day, 1995). }\end{array}$ \\
\hline $\mathbf{2}$ & $\begin{array}{l}\text { Natural } \\
\text { Structuralism-based } \\
\text { approach }\end{array}$ & $\begin{array}{l}\text { Native architecture offers a good model for sustainable architecture } \\
\text { because of its reliance on natural materials and passive environmental } \\
\text { regulation }\end{array}$ & $\begin{array}{l}\text { New Gorna } \\
\text { (Fathi, 1993). }\end{array}$ \\
\hline $\mathbf{3}$ & $\begin{array}{l}\text { Natural modeling } \\
\text { based approach }\end{array}$ & $\begin{array}{l}\text { Indigenous architecture offers the least damage to the ecosystem by } \\
\text { providing eco-friendly forms and denser development and is therefore } \\
\text { an ideal model for sustainable Architecture }\end{array}$ & $\begin{array}{l}\text { Segal } \\
\text { (Towers, 2003). }\end{array}$ \\
\hline $\mathbf{4}$ & $\begin{array}{l}\text { The approach based } \\
\text { on natural absolutism }\end{array}$ & $\begin{array}{l}\text { Native architecture is the product of the evolutionary process of the } \\
\text { environment and is part of the natural environment (the place of human } \\
\text { habitation as a natural species). It is therefore perfectly embodied in } \\
\text { sustainable architecture }\end{array}$ & $\begin{array}{l}\text { Naturalistic projects } \\
\text { Christopher } \\
\text { 1995). }\end{array}$ \\
\hline $\mathbf{5}$ & $\begin{array}{l}\text { Holographic-based } \\
\text { approach }\end{array}$ & $\begin{array}{l}\text { Native architecture as a completely natural phenomenon, derived from } \\
\text { the possibilities of the environment and natural features and relies on } \\
\text { human participation is an immediate product of nature and compatible } \\
\text { with all aspects of the environment. In this respect, it is perfectly } \\
\text { embodied in sustainable architecture }\end{array}$ & \begin{tabular}{l} 
Grameen Bank \\
\hline
\end{tabular} \\
\hline
\end{tabular}

\section{CONCLUSION}

The architecture of temperate and humid regions of Iran is summarized in the following components.

Formations and Proportions: Formation and proportions are two important issues in the architecture formation of these areas. This section deals with the density and height as well as the formation of rooms around the porch. The density and height of the houses of most temperate and humid cities in Mazandaran province are in one or two floors and are scattered around the outer walls with the possibility of moving 
air. Therefore, in these areas the condensation of buildings is low due to the high humidity of air and soil. Near the shore, some of the high-rise houses have been built close to a floor that will remove both the building from humid soil and the height of the sea breeze.

In some cities, the houses are built in two or three floors, which is a response to the climate and to protect the air from moisture and make life sustainable. The establishment of main spaces on the upper floors facilitates the use of airflow. Due to the high soil moisture, the air is usually on the platform or on the pilot. They lack basements. The rooms are mostly open-air and courtyards, with numerous openings in the building and back and forth in the direction of the wind. The use of large colored glass sashes, especially in custom-built houses, has given the main function a dual function. In winter and colder days, the sash closures make the room a warm room, while in the summer or on hot days, the sash lift allows air to circulate and transform the room into a porch. The building must be one layer in order to be connected to the open space on at least two fronts. The spaces must therefore be aligned in a straight line, in the form of a strip built around or in the middle of the main courtyard. These rectangles can also overlap because they occupy less ground on the one hand and on the other hand Better use of airflow increases with height.

Table 3: obeyd Principles of Native Architecture in Moderate Climate (Kasmaei, 1999)

\begin{tabular}{|c|c|c|c|c|c|c|c|c|c|}
\hline $\begin{array}{l}\text { Climate } \\
\text { type }\end{array}$ & $\begin{array}{l}\text { Type of } \\
\text { materials }\end{array}$ & $\begin{array}{l}\text { Type of } \\
\text { plan }\end{array}$ & $\begin{array}{l}\text { Roof } \\
\text { type }\end{array}$ & $\begin{array}{l}\text { Direction } \\
\text { Posture in } \\
\text { the sun }\end{array}$ & $\begin{array}{l}\text { How to } \\
\text { connect } \\
\text { Building to } \\
\text { Earth }\end{array}$ & $\begin{array}{l}\text { Surface } \\
\text { And the } \\
\text { number of } \\
\text { windows }\end{array}$ & $\begin{array}{l}\text { amount } \\
\text { using } \\
\text { Natural } \\
\text { ventilation }\end{array}$ & $\begin{array}{l}\text { Compl } \\
\text { ex } \\
\text { texture }\end{array}$ & $\begin{array}{l}\text { Outer } \\
\text { color } \\
\text { type }\end{array}$ \\
\hline mild & $\begin{array}{l}\text { Low } \\
\text { heating } \\
\text { capacity }\end{array}$ & expanded & Steep & $\begin{array}{l}\text { East to } \\
\text { south }\end{array}$ & $\begin{array}{l}\text { On the } \\
\text { Wooden } \\
\text { stand boards } \\
\text { Or a seat }\end{array}$ & many & many & $\begin{array}{l}\text { Scatter } \\
\text { ed }\end{array}$ & free \\
\hline
\end{tabular}

Spaces and Components: Spaces and components have been of great interest in the architecture of temperate and humid regions. This focuse encompass from the type and shape of spaces in different locations and directions to building components and the climate influence them. In traditional architecture, spaces are divided into three categories: semi-open space, open space and closed space. Closed space consist of rooms.

a- Closed space: The room is about $3.5 \times 3 \mathrm{~m}$ in size, the elements of the rooms are niche, the room is without a closet, and they are nested and connected to each other. Room orientation: East - West. Air conditioning and ventilation can also be provided inside the room from the opposite side. $\mathrm{n}$ the lodge houses, the main room is made of wooden sashes with colored glass in the south or east direction. The rectangular shape of the room is proportional to 1: 3 and even 1 to 4 and it is situated on the second floor to enjoy a wider perspective than to distinguish it from similar types in the desert areas of Iran. Unlike the spaces (biomass spaces) that are scattered and separated in the yard. Residential spaces with special style and location are next to each other and cling to each other. The bulk of the housing stock is larger than other indoor housing components. Room numbers are usually one, two or three and are rarely four or more. The low number of rooms is more than the moderation characteristic of this area, and therefore there is no need for rooms and living spaces dedicated to different seasons and hours of the day, as well as the possibility to use some other spaces, especially the multifunctional porch instead of the room. In this area the rooms are not interconnected and all rooms are owned by one family, the dwelling core is one floor, and in some cases two-story houses are also seen, in the latter case the lower floor. The upstairs living room is the summer living room or the guest room. With this segmentation, the upstairs living room will benefit from the cool breeze that summers higher on the ground, and the downstairs room will be better than the cold winter winds that blow harder and harder, it will be safe. In addition, because the lower room has thicker walls and fewer openings, there is another room, less heat exchange with the outside, making it easier to keep warm and warm for the winter. 
b- Semi-open space: Due to the slight changes in temperature during the day and the appropriate weather conditions during the nine months of the year from late March to early December, semi-open spaces are an essential pillar of traditional architecture in the Caspian coastal region. All the activities of daily living in this area such as cooking, housework, eating, living and even sleeping in summer are done in such spaces.

c- Open space: In the Caspian countryside, the courtyard area is as important as the rest of the house's architectural spaces, with many household chores, especially village social gatherings, cooking, washing utensils, clothing, livestock, matting, fishing nets and other recreation, equipment maintenance. Agriculture, livestock warehouses, agricultural warehouses, ponds, wells, water, etc. are carried out in the backyard or the related elements are located there.

d- House orientation: As the south coast of the Caspian Sea shakes a major breeze from the sea to the shore and vice versa, the assumed line of rooming for many houses is aligned or inclined to the east and west axis. In other cases, this orientation is influenced by the direction of the alley either for the purpose of rejecting aristocracy from adjacent houses or for any other factor, relative to the said axis. Overall, the role of solar radiation in the orientation of houses in this area, as it is in many other places, is not decisive and, in contrast, the direction of airflow and the breeze has a major impact on this because along the main breeze in the area that comes out of the sea or blows into it.

e- Pop-ups: In order to increase the blindness in the rooms, the number of openings is numerous and their surface is wide. As each room except the door usually has two or three windows and even in some houses more than one door. But in reality, these are not doors and are not designed to facilitate people entering and leaving the room. These are the holes that have come in to penetrate the air into the floor. The floor of the windowses are also cut too short, so that the air can reach the surface of the room so people sitting and sleeping can use it.

f- The Nefar: In the past many homes had a summer living space independent of the home's residential core and were referred to as "the Nefar". The building in which Nefar was located was a foyer and each floor had a surface the size of a room, using the enclosed lower floor, which was called "Ben Nefar", instead of the cellar. There was a head space but no wall on Ben Nefar, only the roof pillars and wooden bracelets around the house were protected by crosses between the columns and as a result the air flow was easily maintained. In hot and humid summers these areas were the best place to live and relax. Some of the rural houses in the area still have the Nefar.

g- The way communication between the room and the outside: Between the rooms and in the dwelling core of the house there is never a hallway and corridors and the like. Because these elements weaken the relationship between the room and its entrance to the outside, while the closer the relationship between the two, the more immediate it is. Therefore, unlike the new architecture of the study area, which is more closed space or hard space over soft space and is distant from climate considerations and rooms are connected through corridors in the traditional architecture of connecting rooms with The outer space is based on environmental and climatic constraints in order to provide many functions in addition to creating blinds and airflows. Based on this, the structure of interior and exterior spaces and the periphery of the house can be considered as one of the basic design techniques of residential design in the temperate Caspian region that can be combined with new technology areas, especially building materials. To solve architectural problems.

h- Relation between field and empty space: Surveys show that outdoor space is essential, better protecting the western and northwestern fronts from winter winds. Therefore, if there is a passageway around the ground, the building can be positioned against the front. Otherwise the yard around the building is necessary. An open space on the west side of the building is useful provided that the facade is protected by a tree or any other windshield. 
i- Wall features: Open walls that play the most important role in ventilation. In hot seasons, open and transparent walls should be exposed to the air on one side and exposed to the air on the other, so the openings should be large and wide and also Have wide and wide canopies. The western and northern front windows that are exposed to cold winds in the cold seasons should be covered by protective doors. All canopies are horizontal and meshed to remove heat accumulated underneath the pores and penetrate less indoors and distribute air better in the room.

j- Windows: 1- The windows facing south and southeast have horizontal canopies. 2- The north windows have upright awnings next to the windows, especially on the west side. 3- The windows facing east, west, and adjacent areas have horizontal canopies facing the window. In this area, the horizontal canopy depths of the windows facing south and southeast are about .4 to .5 the height of the window.

$\mathrm{k}$ - Use bushings and adjoining walls to guide the wind: The air inlet and outlet should be as wide as possible on the ground as far as possible, otherwise the air inlet should be larger than its outlet and adjacent to the ground surface, or be provided with horizontal shutters, roof trusses and hand grips. The roof was used to modify the air flow path.

Materials and Construction: Traditional buildings in the Caspian region are named by the type of roofing or wall materials used. Regardless of the traditional building, new building segmentations are also based on the materials of the walls and the type of roofing.

Building segmentation by roofing: Qobadian (2003) Based on roofing, it divides traditional buildings into four major groups. "Gali wearing house"," Lateh-Sar" house, " Simka-house" and " Sofali-house". Also Bazin, Bromberg (1986), according to the climatic conditions and on the basis of roof covering, provide the following classification. Coastal Plains, Galli, Rice Stem, Foothills, Board, Rice Stem and Pottery. \& Brombeerjee (1991) and Memarian (2005) have divided the houses in Caspian Plains based on roofing materials and similar subdivisions. Generally the major roofing materials include rice stems, pottery, boards, Aleppo, tents and mud. In today's situation, the most important roofing materials are Aleppo, Iranite, pottery and dry slopes of flat roofing from materials such as mud or asphalt and concrete(Memarian. 2010).

Building classification by materials: Qobadian (2003) Bazen \& Brombeerjee (1986) Memarian (2005) According to traditional building wall materials in Khazr region as extraverted architectural types are divided into three categories as follows: Darverchin, Nefar and bricks $\&$ adobes. In addition to the aforementioned divisions, new types of new homes with building materials are also common in the Caspian region, which can be added to the aforementioned classification. Building classification based on foundation and seat arrangement: The type of roofing and foundation in the temperate Caspian region has been a function of topographical conditions and access to a variety of materials and on the other hand, the empirical knowledge of local architect and the type of building use, the economic potential of the building owner (Memarian. 2010).

\section{REFERENCES}

Akrami, Gh, Damiar, S. (2017). A New Approach to Native Architecture in its Structural Relation to Sustainable Architecture, Journal of Fine Arts, Architecture and Urban Development, 1(2), 23-32.

Alexander.Ch. (2011). The Nature of the Order of Living Structures in Architecture, Translated by: Reza Sirus Sabri and Ali Akbari, Parham Nagh Publications, Tehran.

Alsope, B. (1992). A New Theory in Architecture, Translated by: Parviz Forouzi, Library Book, Tehran.

Day, Ch. (1995).Places of the Soul, Architectural press is an imprint of Elsevier, UK.

Fathi, H. (1993). Construction with People, Translated by: Ali Ashrafi, University of Art, Tehran.

Gedaali, Q., Afshari, M., \& Sadvandi, M. (2018). Analysis of boushehr vernacular architecture formation in relation to the invironment impact on human temperament. Eat Behav, 7(4), 55-61.

Haeri, M.R. (2005). The Role of Space in Iranian Architecture, Publications of Cultural Research Office, Tehran.

Halabian R. (2012). Operating search of happiness, emotion regulation and the body image of women experience breast surgery. [MA thesis]. Faculty of Education and Psychology. School of Psychology and Educational Sciences, Ardebil University, Iran. 
Kamalipour, H., Memarian, G., \& Mousavian, S. M. F. (2012). Exploring the myth of four in the Persian vernacular architecture, The Myth or Tradition.

Kasmaei, M. (1999). Climate and architecture, reflection poblication with Housing compony.

Memarian, G. H. (2008). Iranian architecture. Tehran: Soroosh Danesh.

Memarian, Gh. (2010). A Survey on the Theoretical Foundations of Architecture, Soroush Danesh Publications, Tehran.

Narimani M. (2012). The effectiveness of impulse control training on emotional processing, impulsivity and distractibility students with dyscalculia. J Learn Disabel, 2 (2), 22-33.

Nourmohammadi, S. (2009). Understanding the Nature of Architectural Space by Reflecting on the Similarity of Space in Indigenous Settlements, Doctoral dissertation on Architecture, Faculty of Architecture, Fine Arts Campus, University of Tehran.

Olivier, M. S. (2003). A layered architecture for privacy-enhancing technologies. South African Computer Journal, 1(31), 53-61.

Qobadian, A. (2003). Climatic Survey of Iranian Traditional Buildings, Tehran: University of Tehran Publications.

Rapoport, B. I., Wattanapanitch, W., Penagos, H. L., Musallam, S., Andersen, R. A., \& Sarpeshkar, R. (2009). A biomimetic adaptive algorithm and low-power architecture for implantable neural decoders. In 2009 Annual International Conference of the IEEE Engineering in Medicine and Biology Society (pp. 4214-4217). IEEE.

Serageldin, I. (2007). Hassan Fathy, published by concept media. Biblitheca Alexandrina Maktabat.

Towers, G. (2003). Building democracy. Routledge.

Yazdanfar, A, Hosseini, B, Zaroudi, M. (2013). Culture and Home Form, Housing and Rural Environment.

\section{SEMBLANZA DE LOS AUTORES}

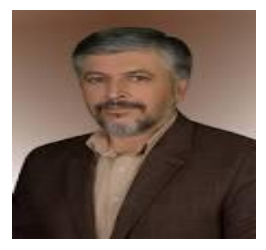

Khosro Daneshjoo: En 1986 se graduó de la Universidad de Teherán en Irán con la licenciatura en arquitectura. En 2000, se graduó de la Universidad de Teherán en Irán con una maestría en arquitectura. La investigación sobre estructuras arquitectónicas, clima y naturaleza en la arquitectura y la planificación urbana es su interés de investigación y actualmente es profesor asistente y miembro de la facultad de la Universidad Tarbiat Modares en Teherán en el campo de la arquitectura y la planificación urbana. 